\title{
Impact of Macro Variables on Karachi Stock Exchange
}

\author{
Rabia Najaf Khakan Najaf \\ University of Lahore, Lahore, Pakistan
}

\begin{abstract}
In this paper we have discussed that stock market of any country act as a predictor of the economy. We have discussed about the role of Pakistani stock markets..There are different topic of stock market in Pakistan but we are discussing Karachi stock exchange .In the case of Pakistan scenario it can be say that Pakistani stock market is act as the true predictor of economic activities .In this paper we have studied that impact of macro variables on Karachi stock exchange. Karachi stock exchange is very interesting topic for the discussion .Karachi stock exchange is known as one of the oldest stock exchange of Asia .Karachi stock exchange is the largest stock exchange of Pakistan .Karachi stock exchange is the dependent variables and inflation, interest rate and exchange rate and GDP are the independent variables .we have taken the data from period 1992 to 2012 . We have found that there is $80 \%$ variation. Therefore we can say there is a strong relationship among the variables .while other variables have shown that GDP, interest rate and inflation has strong relationship with KSE stock index while interest rate have negative relationship with Karachi stock exchange .The increase and decrease the stock prices will affect the performance of the economy .In this paper researcher want to found out the fundamental marc variables which have impact on stock exchange and also want to found out that what are the impact of these variables on the government policies like monetary and facial policy .
\end{abstract}

Keywords: facial policy, monetary policy, Asia, GDP, interest rate, inflation etc.

\section{Introduction}

Karachi stock exchange is very interesting topic for the discussion. In this paper we have find out impact of macro variables on Karachi stock exchange .Karachi stock exchange is known as oldest stock exchange of Asia .Karachi stock exchange is the largest stock exchange of Pakistan. Stock market means the prices of securities which are traded in stock exchange .Stock exchange has a vital role for the fostering capital formation .stock exchange has a main role for the healthy economy of any country .stock exchange is work as a channel between stock investors and stock borrowers .in the words simple stock market is place where we can trade securities .According to different approaches statues that stock market contain two types of investors .one approaches says that investors use their different techniques to overcome the stock market prices and market is insufficient there. The second approaches says that all the investors have the same information ad cannot beat the stock prices . koh (2003) says that share price depends upon the effect of macro variables .keened al (2002) analysis that stock market performance are affected because macroeconomic variables are flotation in nature.lee and Wang (2012) in Thailand stock exchange and stock return have positive relationship .Mohamed et al(2007) analyzed that impact of different variables on stock return .Bollersley (1986)investors are very attractive towards the profits .With the help of determination of value of demand and supply we can know prices of securities which are traded in stock market as daily basis . The fluctuation in stock market due to different factors like economic and political behavior of country .Karachi stock exchange also react due to these factors. In simple words during business hours buyers and sellers exchange their holdings .Stock exchange is the place where investors seek reward in the shape of capital gain .Exchange investment projects is useful to mobilizes the nation s saving. Stock market is the channel between savings and borrower's .According to leading stocks of world reported that negative growth ranging from Pakistan $50.8 \%$ and china $2.7 \%$ during the facial year . Since the last decade the Pakistani stock market was highly disturbed due to financial crises .In March 2005 stock market was crashed in year 2005. The second collage was observed in year 2006.The biggest crash in the may 2008 to January 2009 it was the worst crash in the history of Pakistan .Karachi stock exchange was dropped more than 12 thousand points .There is many reasons due to which prices of demand and supply increases and decrease and have impact on market behavior .According to different researches increase in inflation will increase in the income of demand and supply. The main reason for inflation of any country is there is inverse relationship between demand and supply.According to different economist view that increase in prices of things will indicate the inflation.In other words inflation means expansion of money supply .Many researchers have proved that the rate on inflation has impact on the stock market volatility. Commonly we can say inflation has two main parts 1) expected inflation 2) unexpected inflation .Expected inflation rate is plan one year to year between economists and consumer .Unexpected inflation means that what we can expected between economic and consumers .In this study has shown that main effect of unexpected inflation is due to redistribution of wealth .After the world war 2 in USA the inflation rate is between 3\% to $6 \%$ for many years which has impact On the performance of the stock market inflation created natural bias .Due to inflation in the world every country has worst stock market .In this paper also explores that if government could not control the inflation then worst stock market ratio will 
increase .In the high inflation many assets failed to keep up .Government should control it soon otherwise stock will be collapse over 95\%.Morever,many studies has shown that in the period of high inflation dividend will increase in consumer prices .For the policy point of review stock prices and inflation has relationship. According to farmer (1970) stock market are reflect from the macroeconomic variable therefore it is efficient. Chakravarity (2007) shows that stock market and inflation relationship. .Mukherjee (2002) has shown there is two way causation between stock market performance and inflation .Inflation is due to increase rate and volatility. Inflation has very huge impact on the economic competitiveness. This study has shown that how there is relationship between interest rate and inflation rate. According to different hypothesis high inflation shows high uncertainty. According to li henggua (1998) shows that inflation and stock prices has multiple relationship .According to zhaorang(2001)shows that we cannot consider impact of inflation on stock prices a single factor .Modern economy has common feature is called stock market .Stock market is famous for the development of the economy. After the stock market failure government has enable of raise financing for new projects. The status of investment in stock market is long term .Any variable which has impact on economy also impact of stock exchange. According to different economists inflation is one of the factor which has negative impact of stock exchange .we can measure stock market performance with the help of market capitalization. In this paper we discuss the following issue like 1) what is correlation between stock market and inflation2) how much correlation between stock market liquidity and inflation. .In all the countries inflation caused by monetary authorizes .Therefore, we can say impact of inflation on the stock market has implications on policy market .All the studies shown that stock market performance has effect on the economy. The basic characteristics of this Indian economy that it has strong economic growth.A unique feature of this economy is that it has become second faster economy of the world .In the financial year 2008, 2010 the GDP growth has average near about $6.8 \%$. The target growth rate is $8 \%$ and the growth of Indian s service sector was $9.5 \%$ in $2008-2009$. The best feature of Indian economy that it has high growth .In recent years Asian economy was facing crisis and Indian economy has proven its strength .According to different research foreign exchange reserves has record level in June .In June 2009, the foreign exchange reserves were reach a record level of $300 \mathrm{u}$ \$ dollar .In may 2002, the Indian rupees were in strength as compared to dollar $\mathrm{u} \$ 1=\mathrm{rs}$ 43.51.In 2004, the inflation rate contained at 5.5\% in 2006 the inflation rate was at $6 \%$ and slow down at the beginning of the year 2009 was $9 \%$.

\section{Problem statement:}

Macro variables have impact on the stock exchange.

Hypothesis study:

Kse and interest rate:

H0: market movement will decrease if increase the interest rate

$\mathrm{H} 1$ : increase in interest rate there is no effect on market movement

Kse and inflation:

H0: share movement will increase with increase the inflation.

$\mathrm{H} 1$ : increase in inflation there is no impact of stock market.

Figure no 1:

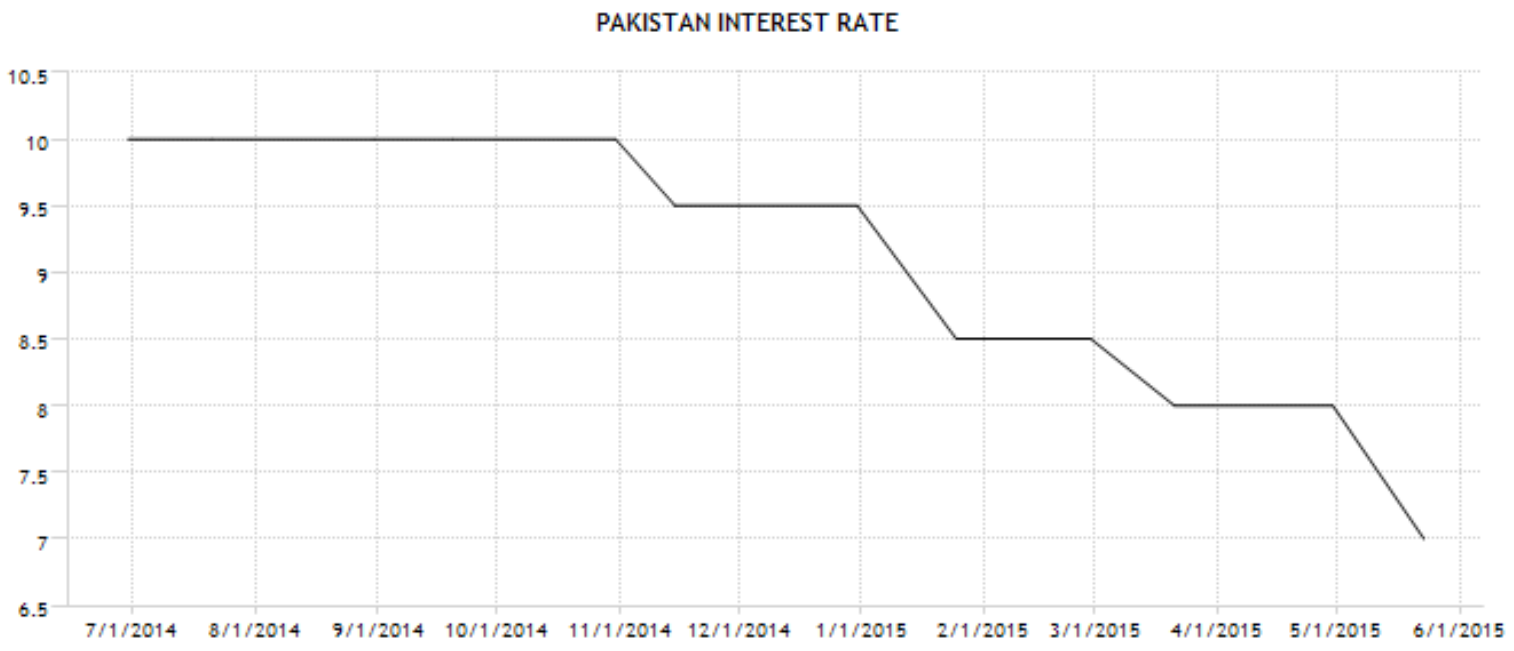


Figure no 2:

\section{PAKISTAN GDP GROWTH RATE}

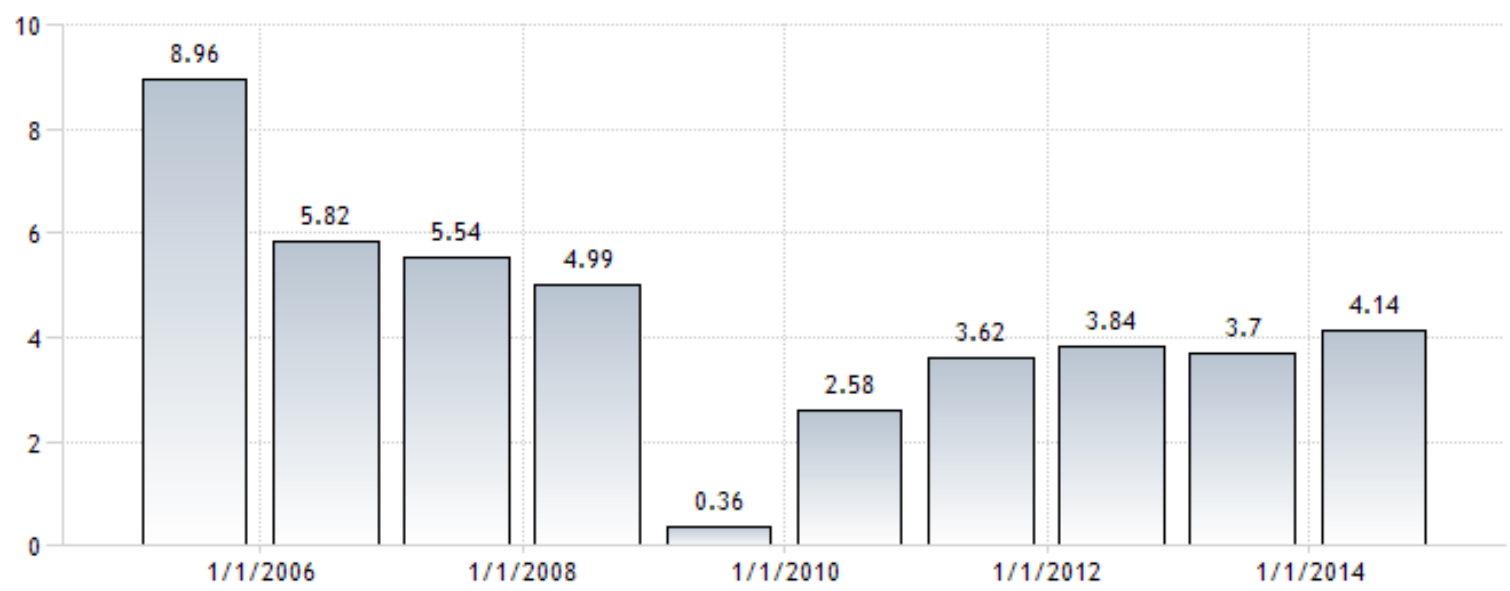

SOURCE: WWW.TRADINGECONOMICS.COM I PAKISTAN BUREAU OF STATISTICS

Figure no 3:

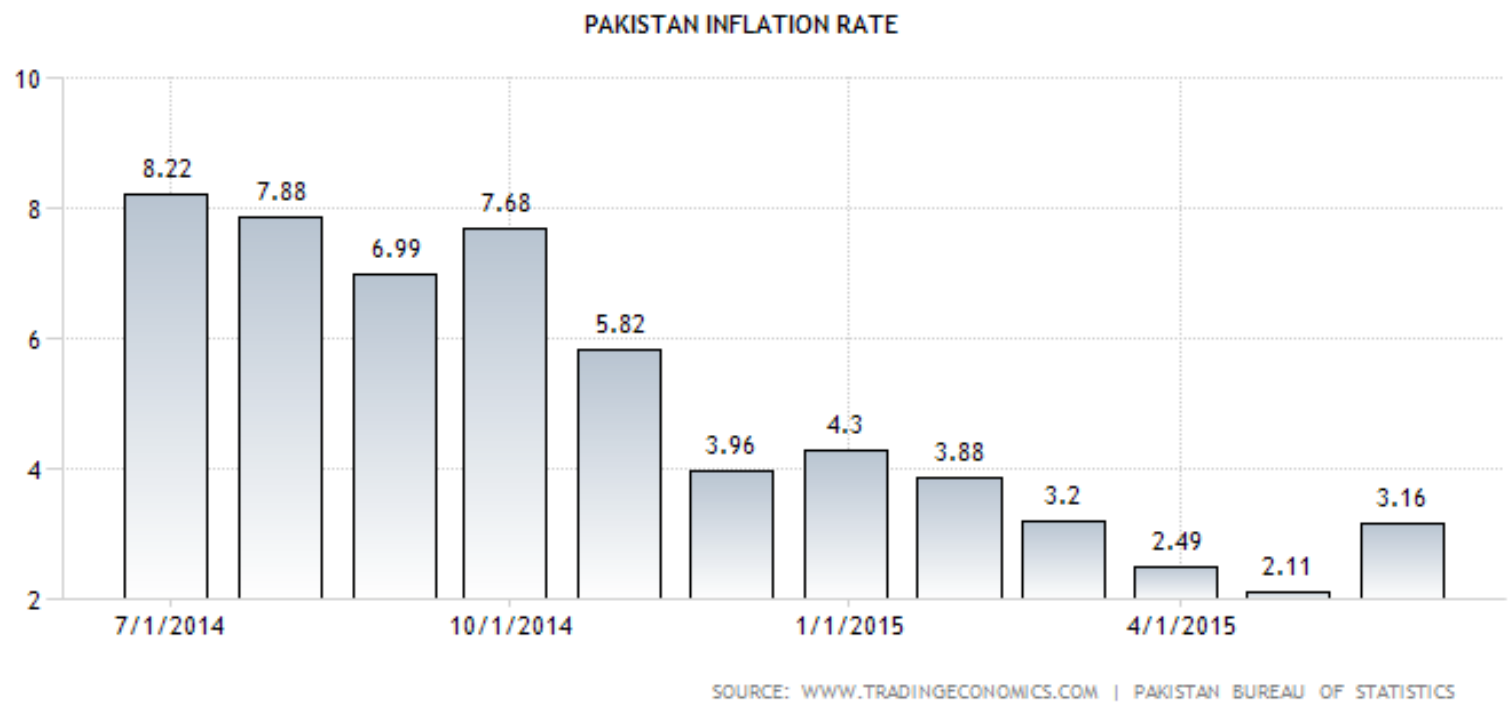

Figure no 4:

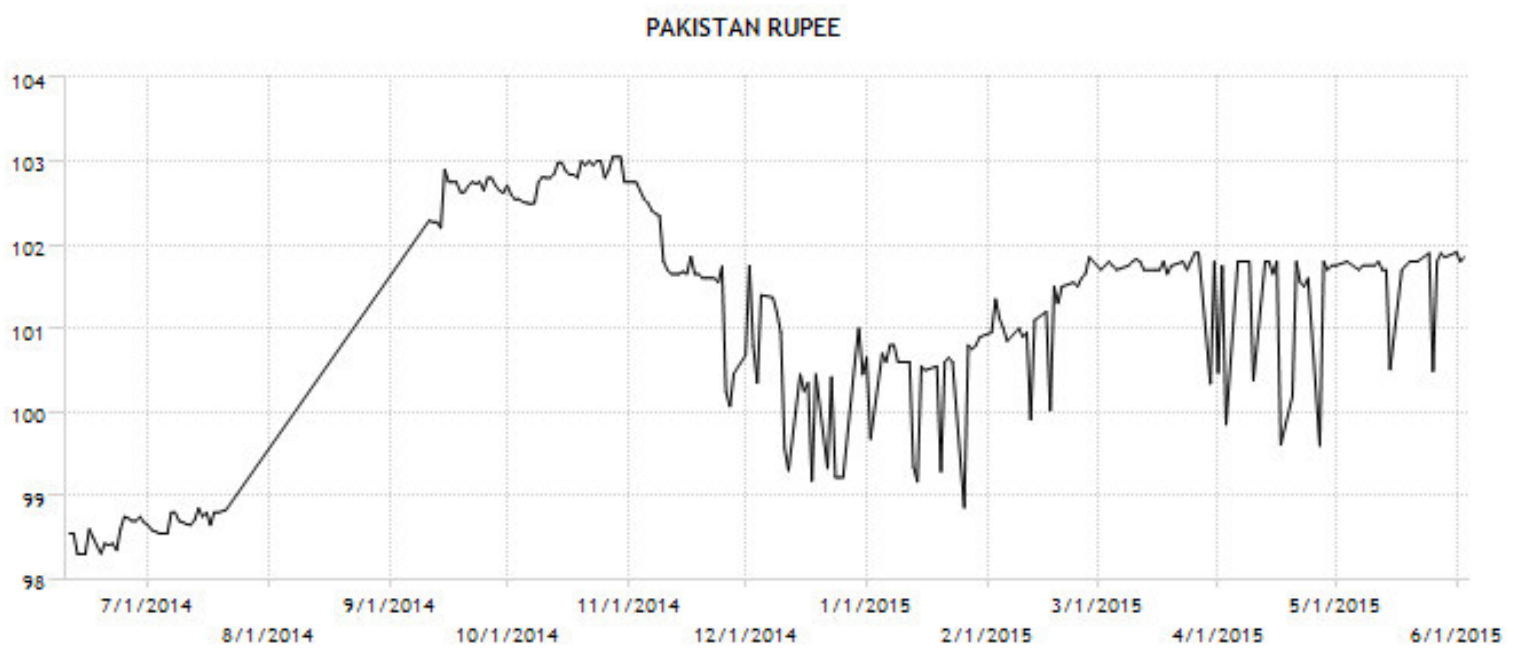

SOURCE: WWW.TRADINGECONOMICS.COM I OTC INTERBANK 
Table 1

Top Ten Biggest Stock Markets in the World (\% of Total)

\begin{tabular}{lll}
\hline No. & Market & $\mathbf{\%}$ \\
\hline 1 & United States & 47.7 \\
2 & Japan & 10.3 \\
3 & United Kingdom & 10.4 \\
4 & France & 4.3 \\
5 & Canada & 3.4 \\
6 & Germany & 2.8 \\
7 & Switzerland & 2.7 \\
8 & Italy & 2.2 \\
9 & Australia & 2.1 \\
10 & Netherlands & 2.1
\end{tabular}

Source: Wren Research, June 2005

\section{Scope of study:}

The scope of this study is find nature and strength of relation between stock return and inflation, and interest rate. Objectives:

1) What are the relationship between stock market and inflation?

2) What are the relationship between stock market and interest rate?

3) What are the relationship between stock market and exchange rate?

\section{THE RESEARCH FRAMEWORK OF This paper;}

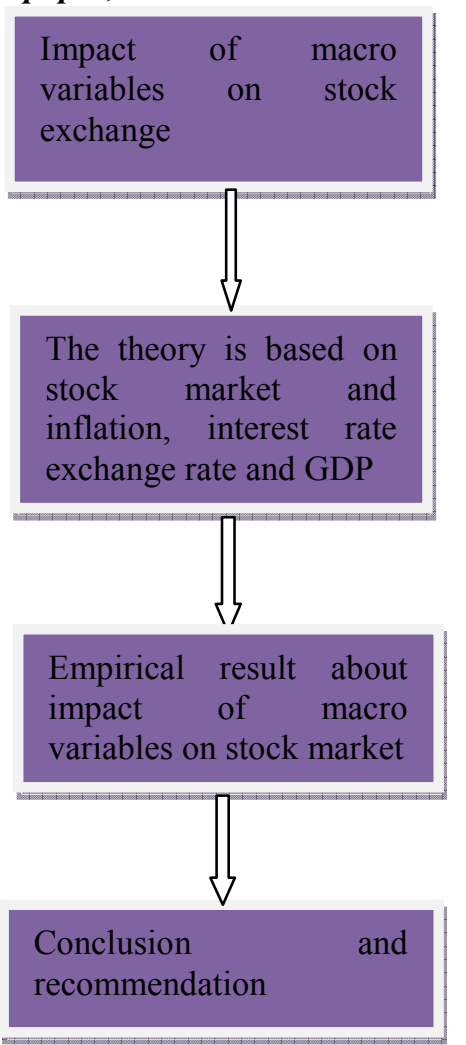

\section{Literature review:}

Different researches have proved that inflation has very negative impact on stock exchange.

LMSC menace (2002) has used the monthly data of Sri lank a stock exchange and from the result of null hypothesis shows that macro variables has no effect on stock markets.

Dubravka benzoic(2003) has shown the impact of macroeconomic factors on stock exchange Indian and for this purpose he used APT theory .

Nish at and shaheen (2005) used the VEM to show the relationship between macovariables and Karachi stock exchange. 
Torso and rjoub in (2008) used APT theory to show the relationship between macro variables and turkey stock exchange.

Rjoub and tursory (2009) conduct the research for the purpose of evaluation of Istanbul stock exchange performance.

Radolfo q adam (2009) found that relationship between share price and bound return.

Butt and rahman (2001) examine risk and investment relationship in firm and industry.

Ahmen buyuksal varchi (2010) has shown the effect of macro factors on china stock exchange.

Rodolfo Aquino(2006) has found out the stock returns of turkey stock exchange.

Gann and lee(2006) has shown that what is relationship between new Zealand stock Market and effect of macro variables on it.

Sohail and Husain (2006) by using the VECM have shown the long run and short run relationship between Karachi stock exchange and different factors.

Twene boah and Adam (2006) has shown that there is negative impact on Ghana stock market.

Mansor and Adam (2009) by using the ganger causality test has shown the causal relationship between macroeconomic variables and stock return.

Mohammad and Husain (2009) show the co movement between macro variables and sri lanka stock exchange. Singh and Mehta (2011) show the relationship between Karachi stock market price and different variables.

Haran and nasir finds that there is negative effect of macro variables on stock exchange.

(Charlesal:2008:hanritaetal,2009:donatas2009; shakil2010) have shown that increase in price of consumer goods have negative impact on stock market and decrease in the price of consumer goods have positive impact on stock price.

Studies have shown that inflation rate affect stock price in all the economy but the relationship between unexpected inflation and stock price still not clear.

According to fisher(1930) studied the fisher hypothesis was exactly apply to stock return and according to different inverse relationship between stock return to unexpected inflation.

(fame and schwert) studies that there is direct relationship between activity and stock return.

Bakshi and Chen (1996) there is no correlation between inflation and stock prices.

Caporole and Jung (1997) studies that there is causal link between expected and unexpected inflation.

Also graham (1996) discussed that there is inverse relationship between inflation and stock prices.

(spyrou2001) by using the data examine the relationship between stock return and inflation rate.

Omran and pointon (2001) by using the co integration analysis and ECM takes the result that inflation rate have impact of Egyptian stock market.

Erdogan an ozlale(2006) studied that impact of macro variables on Turkish stock market and take result that bank interest rate and stock return have negative relationship.

Nish at and shaheen (2006) what is impact of multiple factors on the Karachi stock exchange .there are four factors which have impact on stock prices.

Green pan and Allen (1995) shows that inflation expectations and equity prices have relationship.

Gallagher and Taylor (2002) shows that relationship between stock return and inflation using different multi vative innovation decomposition.

Mashayekh et al (2011) in their research shows there is meaning full relationship of different macroeconomic variables like interest rate, GDP with stock market.

Harsher and libden (2011) investigated the relationship between stock market and exchange rate.

Sharma and Mahindra (2010) shows there is long term relationship of Bombay stock exchange with gold prices. Asoka and ogunmuyiwa (2011) investigate that what is link between share price and Nigerian stock market.

Oskeoe(2010) did a systematic research and show that there is inverse relationship between stock market of Iran and economic growth.

Daferighe and aje(2009) in their study analyzed the impact of economic growth and stock prices of Nigeria.

Shah (2008) studies what are the limitations of stock exchange

Saryal(2006) by using monthly time series shows the effect of multivariable impact on stock prices of sari lank. Erdogan and ozlale (2005) by using the weekly data from period of June 1992 to march 2000 macroeconomic variables on the Turkish stock market.

$\mathrm{Al}$-sharkes (2004) have studied that relationship between Jordanian stock market and macro variables.

Nishat and shaheen (2005) studies the effect of multiple factors on share price of KSE.

Omran and point on(2002) have studied that what is impact of influence on Egyptian stock exchange

Al sharks (2005) explained the relationship between Jordanian stock market and different marcrovaariables.There is long term relationship between Amman stock market and macro variables.

Saryal(2008) analyzed that what is impact of inflation and volatility of turkey and Canada on stock exchange. And also concludes with the increase in inflation stock market become more volatile.

Shah (2009) explained that which factors are creating barriers for Karachi stock exchange. 
Daferighe and aje (2008) explained that what is impact of real gross domestic product on stock prices of Nigeria. And further proved that decrease in prices interest and inflation also impact of stock prices

Menike (2009) has evaluated that what is effect of macro variables on sir Lankan stock market. For this purpose he take monthly time series data of Colombo stock exchange and takes result that inflation rate have negative relationship with CSE

Akinwande (2010) examined that short and long run effect of macro variables on Nigerian capital market Harasheh and libdeh (2012) explained the causality relationship between stock prices and variables of Palestine Sharma and mehendtu(2011) has shown that there is long term relationship between Bombay stock exchange and macro variables.

Daferighe and aje(2010) has studies the impact of GDP on the stock prices of Nigeria

\section{Gaps in literature:}

1) This literature review is just focus on the macroeconomic outcomes not tell properly about the process of these impact

2) In this literate has not shown the positive impact of the macro variables like positive impact of inflation on the economy.

3) In this literature has just focused on the developing country not focused on the under developing country,

4) In this literature has not work properly on the portfolio of risk.

5) In this literature has not shown that what the government is doing against these problems.

\section{Theoretical framework:}

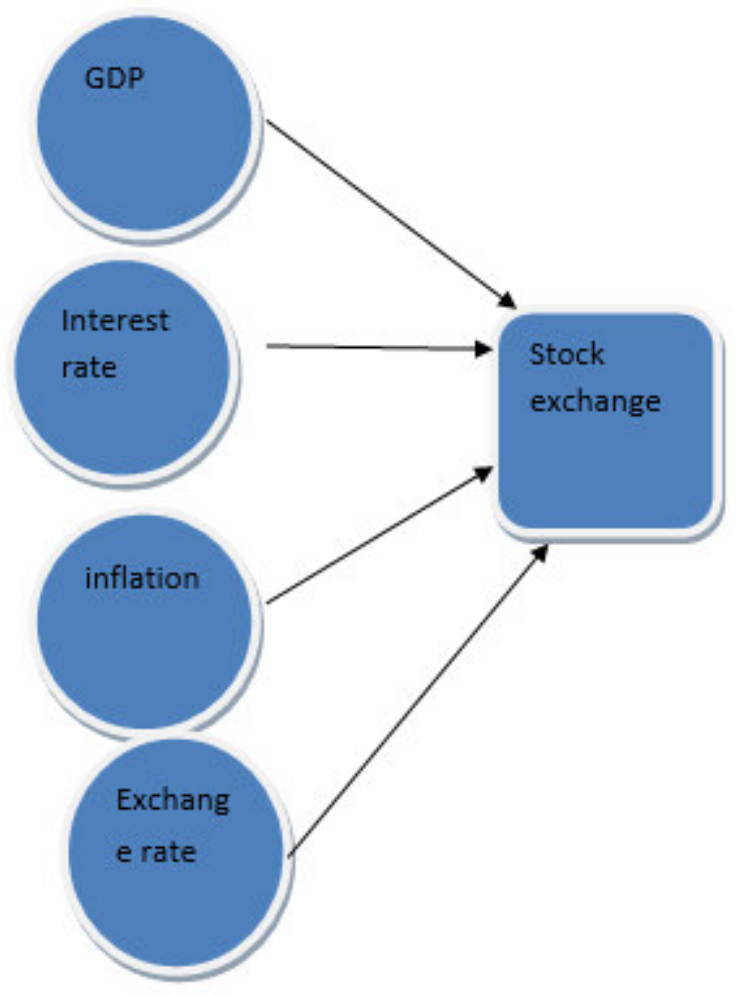

\section{METHODOLOGY:}

For the interpretation of the model we have used Pearson s product movement correlation coefficient and multiple regression models. The purpose of this study is to measure that affect of marc variables on the stock prices of Karachi .we explained the research model by using the different variables .In this model Karachi stock exchange is the dependent variables and other are independent variables. We use yearly data from 1992 to 2012. empirical analysis:

$\mathrm{Y}=\mathrm{a}+\mathrm{b} 1(\mathrm{x} 1)+\mathrm{b} 2(\mathrm{x} 2)+\mathrm{b} 3(\mathrm{x} 3)+\mathrm{b} 4(\mathrm{x} 4)+\mathrm{e}$

$\mathrm{Y}=\mathrm{a}+\mathrm{b} 1(\Delta \mathrm{exc})+\mathrm{b} 2(\Delta \mathrm{gdp})+\mathrm{b} 3(\Delta$ inflation $)+\mathrm{b} 4(\Delta$ int rate $)$

Where $\mathrm{y}=$ dependent variable

$\mathrm{X} 1=$ exchange rate

$\mathrm{X} 2=\mathrm{GDP}$

$\mathrm{X} 3=$ inflation

$\mathrm{X} 4=$ interest rate 


\section{Statistical tools:}

For the interpretation of the model we have used Pearson s product movement correlation coefficient and multiple regression models. Table no 2 shows that there is positive relationship between Karachi stock prices and exchange rate and there is negative relationship between interest rate and Karachi stock prices .At the end 100\% change in independent variable will lead to $5.3033 \%$ change in stock prices .For the purpose of checking that data is significant or not we use t ratio.

\section{Regression equation:}

Table no 1 shows the relationship between dependent variables and independents variables.

$\Delta \mathrm{kse} 100$ index $=\mathrm{a}+\mathrm{b} 1(\Delta \mathrm{ex})+\mathrm{b} 2(\Delta \mathrm{IR})+\mathrm{b} 3(\Delta \mathrm{inf})+\mathrm{b} 4(\Delta \mathrm{GDP})$

All the data have shown that change in the independent variable will cause change in dependent variable .Table no 2 shows that exchange rate, interest rate and GDP has positive and inflation show the negative relationship.

Table no 1:

\begin{tabular}{|c|c|}
\hline Sample size & 20 \\
\hline Coefficient of determination $\mathrm{R}^{2}$ & 0.8098 \\
\hline Readjusted & 0.7591 \\
\hline Multiple correlation coefficient & 0.8998 \\
\hline Residual standard deviation & 21.3378 \\
\hline
\end{tabular}

Table no 2:

\begin{tabular}{|l|c|c|c|c|c|}
\hline $\begin{array}{l}\text { Independent } \\
\text { variables }\end{array}$ & Coefficient & $\begin{array}{c}\text { Std. } \\
\text { Error }\end{array}$ & Partial & $\mathrm{T}$ & $\mathrm{P}$ \\
\hline (Constant) & -65.7771 & & & & \\
\hline Exchange & 1.5386 & 0.3921 & 0.7119 & 3.926 & 0.0015 \\
\hline Interest & -2.3135 & 2.3151 & -0.2499 & -0.998 & 0.3336 \\
\hline Inflation & 4.1828 & 1.3476 & 0.6255 & 3.105 & 0.0074 \\
\hline GDP & 5.3033 & 3.0641 & 0.4081 & 1.732 & 0.1041 \\
\hline
\end{tabular}

Table no 3:

\begin{tabular}{|c|c|c|c|}
\hline Source & DF & Sum of Squares & Mean Square \\
\hline Regression & 4 & 29065.1541 & 7266.2886 \\
\hline Residual & 16 & 6829.5823 & 455.3056 \\
\hline
\end{tabular}

Table no 4:

\begin{tabular}{|r|c|}
\hline F-ratio & 15.9593 \\
\hline Significance level & $\mathrm{P}<0.002$ \\
\hline
\end{tabular}

\section{R2:}

$\mathrm{R} 2$ is used to checking that data is fit or not it ranges normally form 0 to 1.the value of $\mathrm{r} 2$ is 0.8098 which is nearest to 1 .it means there is $80 \%$ variation and this model is good fit.

\section{Pearson s product movement correlation co efficient:}

The purpose of Pearson s product movement correlation is the show the relationship is positive and negative it is represented by $\mathrm{p}$ and denoted by Greek letter .it ranges from +1 to -1 .

Table no 5:

\begin{tabular}{|c|c|}
\hline Variable & $\mathrm{R}$ \\
\hline Exchange & 0.7558 \\
\hline Interest & -0.4301 \\
\hline Inflation & 0.4649 \\
\hline GDP & 0.1538 \\
\hline
\end{tabular}

\section{GDP and KSE 100 index:}

After the evaluation of data in table 5 and 9 shows that have not strong relationship .the model suggests that there is $15.5 \%$ correlation is present.

\section{F ratio:}

The purpose of $\mathrm{f}$ ratio is that overall model is significant or not .for this purpose we use a confidence interval the value of $\mathrm{f}$ ratio in table no 4 is 15.9593 which shows that exchange rate and stock prices are the positive relationship. 
Interest rate and KSE stock prices:

Table no 5 and 7 shows that there is negative relationship between stock exchange and interest rate and correlation is insignificant because value of $0 . .585$ is greater than 0.05 .The study of nishat and shaheen in 2007 shows that there is negative correlation between interest rate and stock prices .when inflation rates moved to high then government should try to control hyper inflation .Increase the rate of has a bad impact on stock prices.

Table no 6:

\begin{tabular}{|c|l|c|c|}
\hline \multicolumn{2}{|c|}{} & KSE & Exchange \\
\hline \multirow{2}{*}{ KSE } & Correlation Coefficient Significance Level Pn & & 0.757 \\
& & & 0.0002 \\
& & & 20 \\
\hline \multirow{3}{*}{ Exchange } & Correlation Coefficient Significance Level Pn & 0.757 & 0.0002 \\
& & 20 & \\
\hline
\end{tabular}

Table no 7:

\begin{tabular}{|c|c|c|c|}
\hline \multicolumn{2}{|c|}{ KSE } & KSE & Interest \\
\hline & Correlation Coefficient & & -0.431 \\
& Significance Level Pn & & 0.0585 \\
& Correlation Coefficient & -0.431 & 20 \\
\hline \multirow{2}{*}{ Interest } & Significance Level Pn & 0.0585 & \\
& & 20 & \\
\hline
\end{tabular}

Table no 8:

\begin{tabular}{|c|c|c|c|}
\hline \multicolumn{2}{|c|}{ KSE } & KSE & Inflation \\
\hline & Correlation Coefficient & & 0.466 \\
& Significance Level Pn & & 0.0388 \\
& Correlation Coefficient & 0.466 & 20 \\
\hline \multirow{2}{*}{ Inflation } & Significance Level Pn & 0.0388 & \\
& & 20 & \\
\hline
\end{tabular}

\section{Inflation rate and KSE 100 index:}

Table no 5 and 8 shows that there is moderate positive relationship between inflation and stock prices index and the $\mathrm{p}$ value is less than 0.05 therefore correlation is significant. For all the tables it has shown that independent variables shows positive and negative and weak correlation.

Table no 9:

\begin{tabular}{|c|c|c|c|}
\hline \multicolumn{2}{|c|}{ KSE } & KSE & GDP \\
\hline & Correlation Coefficient & & 0.155 \\
& Significance Level Pn & & 20 \\
\hline \multirow{2}{*}{ GDP } & Correlation Coefficient & 0.155 & \\
& Significance Level Pn & 0.5172 & \\
& & 20 & \\
\hline
\end{tabular}

Table no 10:

\begin{tabular}{|c|c|c|c|c|c|}
\hline & & Exchange & Interest & Inflation & GDP \\
\hline Exchange & Correlation Coefficient Significance Level Pn & & $\begin{array}{c}-0.437 \\
0.0547 \\
20\end{array}$ & $\begin{array}{c}0.194 \\
0.4158 \\
20\end{array}$ & $\begin{array}{c}-0.219 \\
0.3567 \\
20\end{array}$ \\
\hline Interest & Correlation Coefficient Significance Level Pn & $\begin{array}{c}-0.437 \\
0.0547 \\
20\end{array}$ & & $\begin{array}{r}0.345 \\
0.1382 \\
20\end{array}$ & $\begin{array}{c}-0.418 \\
0.0657 \\
20 \\
\end{array}$ \\
\hline Inflation & Correlation Coefficient Significance Level Pn & $\begin{array}{c}0.194 \\
0.4158 \\
20\end{array}$ & $\begin{array}{c}0.345 \\
0.1382 \\
20\end{array}$ & & $\begin{array}{c}-0.098 \\
0.6788 \\
20\end{array}$ \\
\hline GDP & Correlation Coefficient Significance Level Pn & $\begin{array}{c}-0.219 \\
0.3567 \\
20\end{array}$ & $\begin{array}{c}-0.418 \\
0.0657 \\
20\end{array}$ & $\begin{array}{c}-0.098 \\
0.6788 \\
20\end{array}$ & \\
\hline
\end{tabular}




\section{Conclusion}

We have discussed the brief summary of the paper that changes in the macroeconomic variable have impact on the stock exchange prices in any nation. There are no of variables which have impact on the stock prices.There are three types of stock exchange in Pakistan economy.1)Islamabad stock exchange2)Karachi stock exchange 3)Lahore stock exchange .Karachi stock exchange is one of biggest stock exchange of Pakistan economy and it has capacity to capture $76 \%$ of the capital market of Pakistan .Karachi stock exchange is the backbone of our economy .In the table $\mathrm{r} 2$ is used to check that model is good or not .Value of $\mathrm{r} 2$ shows that model is good .And we used the $t$ test to check that individual significant and $f$ test is used to check that model is significant or not .According to Pearson s correlation model shows that exchange rate and stock prices have positive correlation .There is a moderate positive correlation between inflation and stock exchange .The relationship between interest rate and stock prices is negative. All these relationship has shown that there is not strong correlation among the variables.

\section{Policy Recommended:}

Practitioners and analysts should try to prediction about the future stock prices. They should find out the stock market movement. Investors should forecast how financial market changes. Practitioners and analysts should try to prediction about the future stock prices. They should find out the stock market movement. Investors should forecast how financial market changes. Investment in business operation is very charming business activity .For the outperformance of the market analyst always predict about the stock market and practitioners have role to measurement about risk. All of them try to find relationship between macro variables and stock exchange, on the other hands policymakers should make monetary policy for the adjustment of KSE.

\section{REFERENCES:}

1)Adrangi et al., (1998). Analysed that impact of Inflation, Output and Stock Prices on stock exchange: Evidence from Latin America. Managerial and Decision Economics, 22(2): 64-75.

2)Bakshi, G. S. \& Chen, Z. (1996).what is the impact of Inflation, Asset Prices, and the Term Structure of Interest Rates in Monetary Economies. Review of Financial Studies." Review of Financial Studies, 8: 243-376.

3)Caporale, T. \& Jung, C. (1998). What is the relationship between Inflation and Real Stock Prices. Applied Financial Economics, 8: 266-267.

4)Charles \& Adjasi. (2009). What is Effect of interest Rate Volatility on the Ghana Stock Exchange. African Journal of Accounting, Economics, Finance and Banking Research, 4(5).

5)Chatrath et al., (1996). Impact of Stock Prices, Inflation and Output: Evidence from India. Applied Financial Economics, 8: 438-446.

6)Choudhry, T. (1999).impact of Inflation and Rates of Return on Stocks: Evidence from High Inflation Countries. Discussion Paper, University of Wales Swansea, Department of Economics.

7)Dickey, D. A. \& Fuller, W. A. (1978). Distribution of Estimators of Autoregressive Time Series with a Unit Root. Journal of the American Statistical Association, 75: 428-432.

8)Dickey, D. A. \& Fuller, W. A. (1978, 1982). Likelihood Ratio Tests for Autoregressive Time Series with a Unit Root. Econometrica, 48: 1058-1073.

9)Engle, R. \& Granger, C. W. J. (1988). Cointegration and the error correction representation, estimation and testing. Econometrica, 56: 252-277.

10)Fama, E. (1982). Relationship between Stock Returns, Real Activity, Inflation and Money. American Economic Review, 72: 546-566.

11)Fama, E. \& Schwert ,G. (1978). Relationship between Asset Returns and Inflation. Journal of Business, 56 : 201232.

12) Fisher (1931). Explains the The Theory of Interest. New York:MacMillan 
The IISTE is a pioneer in the Open-Access hosting service and academic event management. The aim of the firm is Accelerating Global Knowledge Sharing.

More information about the firm can be found on the homepage:

http://www.iiste.org

\section{CALL FOR JOURNAL PAPERS}

There are more than 30 peer-reviewed academic journals hosted under the hosting platform.

Prospective authors of journals can find the submission instruction on the following page: http://www.iiste.org/journals/ All the journals articles are available online to the readers all over the world without financial, legal, or technical barriers other than those inseparable from gaining access to the internet itself. Paper version of the journals is also available upon request of readers and authors.

\section{MORE RESOURCES}

Book publication information: http://www.iiste.org/book/

Academic conference: http://www.iiste.org/conference/upcoming-conferences-call-for-paper/

\section{IISTE Knowledge Sharing Partners}

EBSCO, Index Copernicus, Ulrich's Periodicals Directory, JournalTOCS, PKP Open Archives Harvester, Bielefeld Academic Search Engine, Elektronische Zeitschriftenbibliothek EZB, Open J-Gate, OCLC WorldCat, Universe Digtial Library, NewJour, Google Scholar

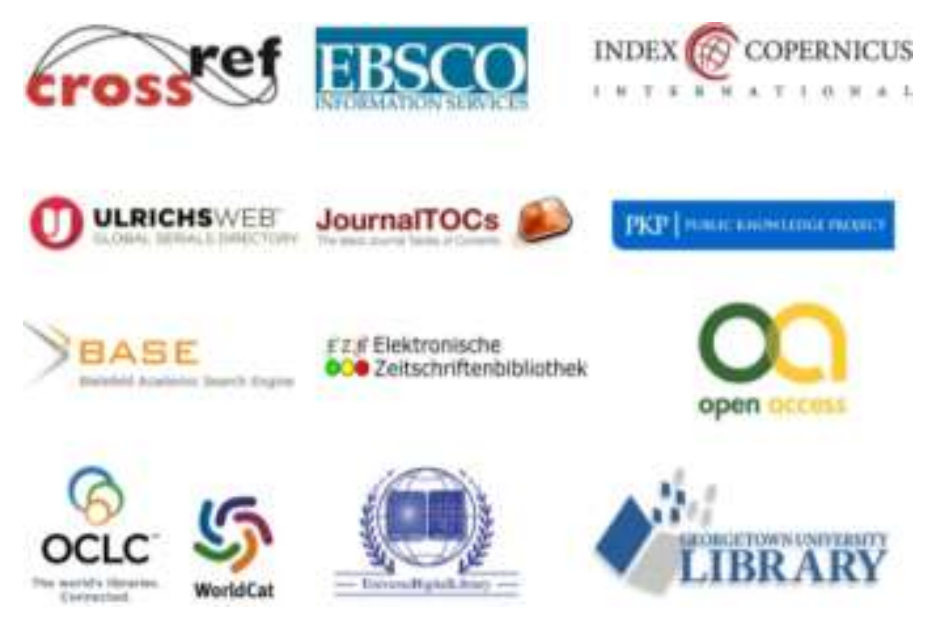

